\title{
Penetration resistance according to penetration rate, cone base size and different soil conditions
}

\author{
Daniel Dias Valadão Junior ( ${ }^{\text {* }}$; Aloísio Biachini $\left({ }^{2}\right)$; Franciele Caroline Assis Valadão (1); Rodrigo \\ Pengo Rosa $\left({ }^{2}\right)$ \\ (') Instituto Federal de Mato Grosso (IFMT), Campus Campo Novo do Parecis, 78360-000 Campo Novo do Parecis (MT), Brasil. \\ (2) Universidade Federal de Mato Grosso (UFMT), Faculdade de Agronomia, Medicina, Veterinária e Zootecnia, Cuiabá (MT), Brasil. \\ (*) Corresponding author: daniel.valadao@cnp.ifmt.edu.br
}

Received: Nov. 12, 2013; Accepted: Feb. 13, 2014

\begin{abstract}
This study aimed to evaluate the effect of penetration rate and the size of the cone base on the resistance to penetration under different soil moistures and soil bulk density. The experimental design was completely randomized in a $4 \times 2 \times 2 \times 2$ factorial arrangement, with the factors, soil bulk density of 1.0; 1.2; 1.4 and $1.6 \mathrm{Mg} \mathrm{m}^{-3}$, soil moisture at the evaluation of 0.16 and $0.22 \mathrm{~kg} \mathrm{~kg}^{-1}$, penetration rates of 0.166 and $30 \mathrm{~mm} \mathrm{~s}^{-1}$ and areas of the cone base of 10.98 and $129.28 \mathrm{~mm}^{2}$ resulting in 32 treatments with 8 replicates. To ensure greater uniformity and similarity to field conditions, samples passed through cycles of wetting and drying. Only the interaction of the four factors was not significant. Resistance values varied with the density of the soil, regardless of moisture and penetration rate. Soil penetration resistance was influenced by the size of the cone base, with higher values for the smallest base independent of moisture and soil bulk density. The relationship between resistance to penetration and moisture is not always linear, once it is influenced by soil bulk density. Reduction in the area of the cone leads to an increase in the soil resistance to penetration.
\end{abstract}

Key words: soil bulk density, soil moisture, methodology.

\section{Resistência do solo à penetração em função da velocidade de penetração, tamanho da base do cone e diferentes condições do solo}

\section{Resumo}

O objetivo do trabalho foi avaliar o efeito da velocidade de penetração e do tamanho da base do cone na resistência do solo à penetração sob diferentes condições de umidade e densidade do solo. O delineamento adotado foi o inteiramente casualizado, em esquema fatorial $4 \times 2 \times 2 \times 2$, tendo como fatores a densidade de solo de 1,0, 1,2, 1,4 e 1,6 $\mathrm{Mg} \mathrm{m}^{-3}$, a umidade de solo, no momento da avaliação, de 0,16 e $0,22 \mathrm{~kg} \mathrm{~kg}^{-1}$, a velocidade de penetração de $0,166 \mathrm{~mm} \mathrm{~s}^{-1}$ e de $30 \mathrm{~mm} \mathrm{~s}^{-1}$ e o tamanho da área da base do cone de 10,98 mm² e de 129,28 mm², resultando em 32 tratamentos com oito repetições. Visando dar maior uniformidade e maior semelhança às condições de campo, as amostras passaram por ciclos de umedecimento e secagem. Apenas a interação dos quatro fatores não foi significativa. Os valores de resistência variaram com a densidade do solo, independentemente da umidade e da velocidade de penetração. A resistência do solo à penetração foi influenciada pelo tamanho da base do cone, com a menor base apresentando os maiores valores, independentemente da umidade e da densidade do solo. A relação entre resistência do solo à penetração e umidade nem sempre é linear, pois é influenciada pelo valor da densidade do solo. A diminuição do tamanho da base do cone provoca incremento no valor da resistência do solo à penetração.

Palavras-chave: densidade do solo, umidade do solo, metodologia. 


\section{INTRODUCTION}

The resistance to penetration has been the physical attribute prioritized by soil science, by directly influencing root growth and consequently the shoots and productivity. Despite the existence of the relationship, many researches try to find the exact individual contribution of physical factors that make up the soil, and their real influence on root growth (Assis et al., 2009; Reichert et al., 2009; Tormena et al., 2007). The interest in resistance stems from the ease and speed of obtaining results, and because it is considered as an integrating index of several soil characteristics (Dexter et al., 2007).

Equipment used in the field to measure the resistance, called penetrometers or penetrographers, follow standards set by the American Society of Agricultural and Biological Engineers (ASABE, 2006a,b), which determines that such equipment must allow the creation of a common method, enabling comparison between different research centers. According to the standard, the test should be performed with a constant rate of $30 \mathrm{~mm} \mathrm{~s}^{-1}$, using a $30^{\circ}$ angle cone and base area of $129.28 \mathrm{~mm}^{2}$ when on hard surfaces, the reality of most Brazilian soils.

With the studies on optimal water range proposed by Letey (1985) and currently studied by several researchers, a new category of devices has emerged called bench top penetrographer, with large variation regarding the methodology proposed by ASABE (2006a,b). These penetrographers began to be used by allowing the determination on undisturbed samples with greater precision in adjusting the mathematical relationships between resistance, volumetric water content and soil bulk density (Sá et al., 2007). In the case of these penetrographers they must have constant penetration rate and speed below $8.2 \mathrm{~mm} \mathrm{~s}^{-1}$ (Lowery and Morrison Junior, 2002).

Few studies have attempted to elucidate the behavior of the penetration resistance due to the speed and size of the cone. Among them, stand out the studies of Spektor (1981) and Hernanz et al. (2000), which worked with varying sizes of cone base. Both studies observed an indirect relationship between the size of the cone base and the variation range and values of resistance. According to Hendrick and Gill (1973), at high penetration rates there is evidence of a decrease in the plastic deformation zone, reducing the resistance value. If this evidence is true, the comparison between the values obtained in laboratory and those found under field conditions becomes unfeasible.

The range of penetration rates used for penetrometer analysis is wide (Figueiredo et al., 2011), but when assessing Brazilian studies with optimal water range, it is observed that the predominant rate used for the analysis of resistance under laboratory conditions is $0.166 \mathrm{~mm} \mathrm{~s}^{-1}$ (Bergamin et al., 2010; Beutler et al., 2007), but with a wide variation in methodology among studies and in relation to the original methodology, not taking into account variations caused by penetration rate and cone size.

The goal of the present study was to evaluate the effect of penetration rate and area of the cone base on soil resistance to penetration under two moisture conditions in soil samples with different soil bulk density.

\section{MATERIAL AND METHODS}

The experiment was conducted in a controlled environment. The soil was a Latossolo Vermelho-Amarelo distrófico with clayey-sandy texture (EMBRAPA, 2006) with $380 \mathrm{~g} \mathrm{~kg}^{-1}$ clay, $104 \mathrm{~g} \mathrm{~kg}^{-1}$ silt and $516 \mathrm{~g} \mathrm{~kg}^{-1}$ sand. For soil characterization, we conducted the standard Proctor compaction testing and obtained the equation for soil bulk density according to moisture: $\mathrm{SD}=-43.22 \mathrm{M}^{2}+18.63 \mathrm{M}-0.097$. From the equation, it was determined the optimum water content for compaction, $0.21 \mathrm{~kg} \mathrm{~kg}^{-1}$, and the maximum soil bulk density, $1.91 \mathrm{Mg} \mathrm{m}^{-3}$.

The experimental design was completely randomized in a $4 \times 2 \times 2 \times 2$ factorial arrangement, with the factors, soil bulk density of $1.0 ; 1.2 ; 1.4$ and $1.6 \mathrm{Mg} \mathrm{m}^{-3}$, soil moisture at the evaluation of 0.16 and $0.22 \mathrm{~kg} \mathrm{~kg}^{-1}$, penetration rates of 0.166 and $30 \mathrm{~mm} \mathrm{~s}^{-1}$ and areas of the cone base of 10.98 and $129.28 \mathrm{~mm}^{2}$ resulting in 32 treatments with 8 replicates, amounting to 256 plots.

The penetration rates and cone base areas used were based on values most recurrent in the literature when working with optimal water range and the values established by ASABE standard $(2006 a, b)$. In the construction of cones and rods we respected the ratio proposed by the standard as well as the characteristics of the material, i.e. stainless steel with maximum roughness of 63 micro inches.

For mounting the samples, PVC cylinder $5 \mathrm{~mm}$ wall thick, $100 \mathrm{~mm}$ height and $150 \mathrm{~mm}$ diameter were made. The cylinder was chosen so that there were no influences of its diameter when obtaining data, and no changes in volume caused by the strength used at the time of compression, thus ensuring the desired density of the soil.

The soil for the study was collected in area of natural vegetation, predominantly grasses, from the $20-200 \mathrm{~mm}$ layer, aiming to eliminate most part of undecayed organic matter and plant roots on the surface. After the collection, soil was air dried and sieved at $4 \mathrm{~mm}$. Next, moisture was determined and, 48 hours before testing, water was added to the non-limiting water range obtained by standard Proctor test. After this, soil was sealed to prevent water loss and to ensure even distribution of moisture.

In order to mount the cylinders, soil was weighed and, based on its dry mass, it was determined the amount of soil required to reach the desired density according to the volume of the cylinder. At soil bulk density of 1.2, 1.4 and 1.6, $\mathrm{Mg} \mathrm{m}^{-3}$ that amount was divided in half. Compaction was 
performed in two steps using a hydraulic press of $5000 \mathrm{kgf}$ capacity, piston diameter $1.5 \mathrm{~mm}$ smaller than the cylinder.

To ensure greater uniformity and similarity to field conditions, cylinders were subjected to a curing period. To this end, soon after mounting, the cylinders were saturated and handled for cycles of wetting and drying. For soil saturation water was added in sufficient amount in a container beneath the cylinder so that saturation occurred by capillarity. After 24 hours of the rise of the liquid to the surface, excess water on the base was discarded. To monitor drying, cylinders were weighed every 2 days and considered dried when the weight remained constant in 3 subsequent weighings. The assessment occurred after 12 wetting and drying cycles. At that time, cylinders were weighed and the water content adjusted to the desired moisture content. To ensure uniformity in the moisture inside the cylinder they were kept in a moist chamber for 72 hours to prevent moisture loss, and to allow the distribution more homogeneous as possible.

The resistance to penetration was measured by an automated bench top electronic penetrometer. The penetrometer was equipped with data acquisition module (HBM MX840A), which records the time and strength obtained in the tests. The choice of MX840A module was due to its reading speed and information capture that can reach $19,000 \mathrm{~Hz}$, which allows a detailed evaluation the phenomena that occur during a penetration test. The frequency of data acquisition used in the experiment was $9,600 \mathrm{~Hz}$ at the fastest speed, that is, one point for every $0.0031 \mathrm{~mm}$ and $300 \mathrm{~Hz}$ at the lowest speed, one point for every $0.00055 \mathrm{~mm}$. These acquisition frequencies were chosen to allow as many points as possible and the manipulation of the worksheet. This module is connected to a load cell with a capacity of $100 \mathrm{~kg}$, sensitivity $2 \mathrm{mv} \mathrm{V} \mathrm{V}^{-1}(+/-10 \%)$ and combined error $<0.03 \%$. The collected data were stored and further processed with Microsoft Excel.

To calculate the soil resistance of the medium penetration to be used in analysis of variance, we disregarded penetration data relating to the time at which the cone was not totally into the ground, and data relating to the final $5 \mathrm{~mm}$ of the test. Data were subjected to analysis of variance using the F-test and when significant $(\mathrm{p}<0.05)$ we applied a ScottKnott test to compare means of moisture and size of the cone base and regression to soil bulk density. Statistical analyses were run using MINITAB 16 (2012).

\section{RESULTS AND DISCUSSION}

Using the F-test, it was observed no quadruple interaction between soil bulk density, moisture, penetration rate and area of the cone base, however, all triple interactions were significant.

Table 1 lists the breakdown of the interaction between soil bulk density, moisture and penetration rate.

Resistance values vary with soil bulk density independent of the moisture and penetration rate (Figure 1a) fitting to linear models (Table 2). In the case of the penetration rate, the behavior was more complex, at the lower moisture only at the density of $1.0 \mathrm{Mg} \mathrm{m}^{-3}$, the values were similar. At the moisture of $0.22 \mathrm{~kg} \mathrm{~kg}^{-1}$ only the density $1.2 \mathrm{Mg} \mathrm{m}^{-3}$ was different. Comparing the values obtained for the soil moisture, it was noted that moisture had no effect on the value of the soil penetration resistance at the lowest soil bulk density.

The variation in the results according to the rate can be explained by complex interactions between the rate and strength of penetration, in which a small increase in the penetration rate of the cone can have a positive, negative or no influence on measurements of soil penetration resistance (Figueiredo et al., 2011). This is due, for example, to the rate of energy dissipation, and also to dilatancy properties of soil in particular (Bradford, 1986). In this context, Lowery and Morrison Junior (2002) argue that constant rates of cone penetration below $8.3 \mathrm{~mm} \mathrm{~s}^{-1}$ are common in the laboratory, and satisfactory in the field.

In accordance with Cunha et al. (2002) the penetration resistance of the soil is highly related to water content and soil bulk density, and the increase in soil bulk density and decrease in water content causes a linear increase of the resistance. However, it should be noted that this relationship is not always linear and the effect of moisture is dependent on the soil bulk density, as evidenced by the lack of significant difference at the density of $1.0 \mathrm{Mg} \mathrm{m}^{-3}$. Gomes and Peña (1996) found that close to maximum soil bulk density, small

Table 1. Soil penetration resistance (Mpa) according to soil bulk density, moisture and penetration rate of the cone

\begin{tabular}{|c|c|c|c|c|c|}
\hline \multirow{2}{*}{$\begin{array}{l}\text { Moisture } \\
\left(\mathbf{k g ~ k g}^{-1}\right)\end{array}$} & \multirow{2}{*}{$\begin{array}{l}\text { Penetration rate } \\
\qquad\left(\mathrm{mm} \mathrm{s}^{-1}\right)\end{array}$} & \multicolumn{4}{|c|}{ Bulk density $\left(\mathrm{Mg} \mathrm{m}^{-3}\right)$} \\
\hline & & 1.00 & 1.20 & 1.40 & 1.60 \\
\hline \multirow{2}{*}{0.160} & 0.166 & $0.59 \mathrm{aa}$ & $1.66 \mathrm{ba}$ & $3.54 \mathrm{ba}$ & 6.97ba \\
\hline & 30 & $0.74 \mathrm{aa}$ & $2.11 \mathrm{aa}$ & $4.73 \mathrm{aa}$ & 7.29aa \\
\hline \multirow{2}{*}{0.220} & 0.166 & $0.53 a a$ & $1.29 \mathrm{~b} \beta$ & $2.91 \mathrm{a} \beta$ & $4.51 \mathrm{a} \beta$ \\
\hline & 30 & $0.61 \mathrm{aa}$ & $1.54 \mathrm{a} \beta$ & $2.80 \mathrm{a} \beta$ & $4.70 \mathrm{a} \beta$ \\
\hline \multicolumn{6}{|c|}{$\mathrm{DMS}_{\text {(moisture) }}=0.247 \mathrm{DMS}_{(\text {rate) }}=0.247 \mathrm{CV}(\%)=10.54$} \\
\hline
\end{tabular}




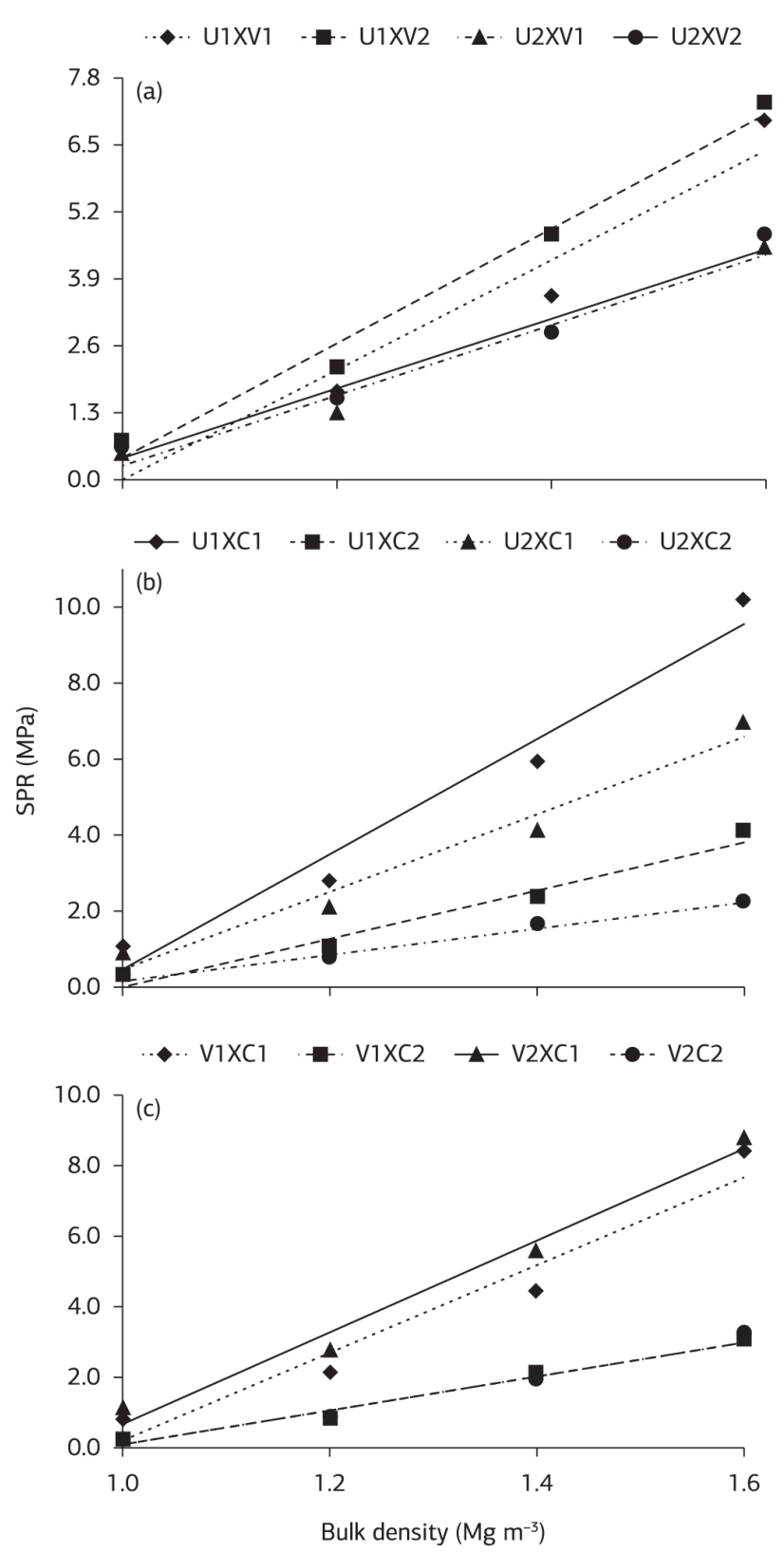

Figure 1. Soil penetration resistance (SPR) according to soil bulk density and interactions with moisture, penetration rate and area of the cone base. (a) Interaction with moisture and penetration rate. (b) Interaction with moisture and area of the cone base. (c) Interaction with penetration rate and area of the cone base.

variations in density cause large variations in resistance to penetration and the effect of moisture is higher in compacted and more clayey soils.

Table 3 shows the breakdown between soil bulk density, moisture, and area of the cone base. Again regardless of the combination, the value of the resistance to penetration differed depending on the density of the soil, when increased linearly (Figure 1b). By observing figure $1 \mathrm{~b}$ and the models presented in table 2, the cone of smaller base showed higher slope, showing a greater increase in resistance due to the
Table 2 . Regression models for soil penetration resistance according to soil bulk density, and interactions with moisture, penetration rate and area of the cone base

\begin{tabular}{|c|c|c|c|}
\hline \multicolumn{4}{|c|}{ Moisture and penetration rate } \\
\hline \multirow{2}{*}{ Interaction } & \multicolumn{2}{|c|}{ Model parameters* } & \multirow{2}{*}{$\mathbf{R}^{2}$} \\
\hline & $\mathbf{a}$ & b & \\
\hline U1XV1 & -10.47 & 10.51 & 0.94 \\
\hline U1XV2 & -10.76 & 11.13 & 0.98 \\
\hline U2XV1 & -6.50 & 6.78 & 0.98 \\
\hline U2XV2 & -6.32 & 6.76 & 0.97 \\
\hline \multicolumn{4}{|c|}{ Moisture and area of the cone base } \\
\hline \multirow[t]{2}{*}{ Interaction } & \multicolumn{2}{|c|}{ Model parameters* } & \multirow[t]{2}{*}{$\mathbf{R}^{2}$} \\
\hline & a & B & \\
\hline $\mathrm{U} 1 \mathrm{XC1}$ & -14.84 & 15.25 & 0.97 \\
\hline $\mathrm{U} 1 \mathrm{XC2}$ & -6.35 & 6.36 & 0.97 \\
\hline $\mathrm{U} 2 \mathrm{XC1}$ & -9.67 & 10.16 & 0.97 \\
\hline U2XC2 & -3.23 & 3.39 & 0.99 \\
\hline \multicolumn{4}{|c|}{ Penetration rate and area of the cone base } \\
\hline \multirow[t]{2}{*}{ Interaction } & \multicolumn{2}{|c|}{ Model parameters* } & \multirow[t]{2}{*}{$\mathbf{R}^{2}$} \\
\hline & $\mathbf{a}$ & b & \\
\hline $\mathrm{V} 1 \mathrm{XC1}$ & -12.34 & 12.44 & 0.94 \\
\hline $\mathrm{V} 1 \mathrm{XC2}$ & -4.72 & 4.83 & 0.98 \\
\hline $\mathrm{V} 2 \mathrm{XC1}$ & -12.29 & 12.97 & 0.98 \\
\hline $\mathrm{V} 2 \mathrm{XC2}$ & -4.85 & 4.93 & 0.98 \\
\hline
\end{tabular}

*significant at 0.05 probability by the F-test. U1: soil moisture at $0.16 \mathrm{~kg} \mathrm{~kg}^{-1}$; U2: soil moisture at $0.22 \mathrm{~kg} \mathrm{~kg}^{-1}$; V1: penetration rate at $0.16 \mathrm{~mm} \mathrm{~s}^{-1}$; V2: penetration rate at $30 \mathrm{~mm} \mathrm{~s}^{-1}$. C1: area of the cone base at $10.98 \mathrm{~mm}^{2} ; \mathrm{C} 2$ : area of the cone base at $129.28 \mathrm{~mm}^{2}$

variation of soil bulk density. This may indicate a higher sensitivity of the cone to capture small differences in the structural arrangement of the soil, and is therefore more appropriate to indicate the actual soil resistance.

The resistance to penetration was influenced by the area of the cone base; the smaller base showed higher values, independent of moisture and density. Similarly to the previous breakdown, at a density of $\mathrm{Mg} \mathrm{m}^{-3}$, the moisture had no influence on the values of soil resistance to penetration; this probably occurred by the distance between the soil particles impeding a lubricating effect of moisture during cone penetration.

In the case of increasing penetration resistance as a function of the reduction of the base area, similar results were observed by Hernanz et al. (2000). These authors noted that in addition to increases in resistance values according to reduction in area of the cone base, data variation also increased, thus requiring a greater number of samples to maintain an acceptable coefficient of variation. When the size of the cone base exceeded $100 \mathrm{~mm}^{2}$, values became constant, thus independent from the base area. This probably occurs because the greater the size of the cone, the larger the volume of soil explored and hence smaller variation in values obtained by the mean effect. When the cone is small, resistances obtained are more punctual and therefore 
Table 3. Soil penetration resistance (MPa) according to soil bulk density, moisture and area of the cone base

\begin{tabular}{|c|c|c|c|c|c|}
\hline \multirow{2}{*}{$\begin{array}{l}\text { Moisture } \\
\left(\mathbf{k g ~ k g}^{-1}\right)\end{array}$} & \multirow{2}{*}{$\begin{array}{l}\text { Area of the cone base } \\
\qquad\left(\mathrm{mm}^{2}\right)\end{array}$} & \multicolumn{4}{|c|}{ Bulk density $\left(\mathrm{Mg} \mathrm{m}^{-3}\right)$} \\
\hline & & 1.00 & 1.20 & 1.40 & 1.60 \\
\hline \multirow{2}{*}{0.160} & 10.98 & $1.06 \mathrm{a} \alpha$ & $2.78 \mathrm{a} \alpha$ & $5.92 \mathrm{a} \alpha$ & $10.18 \mathrm{a} \alpha$ \\
\hline & 129.28 & $0.28 \mathrm{~b} \alpha$ & $0.99 \mathrm{~b} \alpha$ & $2.35 \mathrm{~b} \alpha$ & $4.07 \mathrm{~b} \alpha$ \\
\hline \multirow{2}{*}{0.220} & 10.98 & $0.90 \mathrm{a} \alpha$ & $2.12 \mathrm{a} \beta$ & $4.11 \mathrm{a} \beta$ & $7.01 \mathrm{a} \beta$ \\
\hline & 129.28 & $0.24 \mathrm{~b} \alpha$ & $0.72 \mathrm{~b} \beta$ & $1.60 \mathrm{~b} \beta$ & $2.21 \mathrm{~b} \beta$ \\
\hline
\end{tabular}

$\mathrm{DS}_{\text {(moisture) }}=0.247 \mathrm{DMS}_{\text {(cone) }}=0.247 \mathrm{CV}(\%)=1$

Lowercase letters: compares the area of the cone base by setting the moisture and soil bulk density. Greek letters: compares the moisture by setting the area of the cone base and soil bulk density. Means followed by the same letter are not significantly different by Scott-Knott test, at 0.05 probability. DMS: least significant difference. CV: coefficient of variation.

Table 4. Soil penetration resistance (MPa) according to soil bulk density, penetration rate and area of the cone base

\begin{tabular}{|c|c|c|c|c|c|}
\hline \multirow{2}{*}{$\begin{array}{c}\text { Penetration rate } \\
\left(\mathrm{mm} \mathrm{s}^{-1}\right)\end{array}$} & \multirow{2}{*}{$\begin{array}{l}\text { Area of the cone } \\
\text { base }\left(\mathrm{mm}^{2}\right)\end{array}$} & \multicolumn{4}{|c|}{ Bulk density $\left(\mathrm{Mg} \mathrm{m}^{-3}\right)$} \\
\hline & & 1.00 & 1.20 & 1.40 & 1.60 \\
\hline \multirow{2}{*}{0.166} & 10.98 & $0.84 a \beta$ & $2.13 a \beta$ & $4.43 a \beta$ & $8.37 a \beta$ \\
\hline & 129.28 & $0.28 \mathrm{ba}$ & $0.83 \mathrm{ba}$ & $2.03 \mathrm{ba}$ & $3.10 \mathrm{ba}$ \\
\hline \multirow{2}{*}{30} & 10.98 & $1.11 \mathrm{aa}$ & $2.78 \mathrm{aa}$ & $5.60 \mathrm{aa}$ & $8.82 \mathrm{aa}$ \\
\hline & 129.28 & $0.24 \mathrm{ba}$ & $0.88 \mathrm{ba}$ & $1.92 \mathrm{ba}$ & $3.18 \mathrm{ba}$ \\
\hline \multicolumn{6}{|c|}{$\mathrm{DMS}_{\text {(rate) }}=0.247 \mathrm{DMS}_{\text {(cone) }}=0.247 \mathrm{CV}(\%)=10.54$} \\
\hline
\end{tabular}

data variation is larger, since the soil is not a homogeneous medium.

The fact that the area of the cone base affects the soil penetration could be explained by the way the cone penetrates into the soil. For the penetration, the cone needs to produce cracks ahead. In the case of the larger cone, due to its larger volume, the cracks produced by its passage are greater, and then much of the time it penetrates without resistance, attaining lower mean values than the smaller cone. This suggests the existence of soil rupture plans in front of the tool (cone), as described in the prediction model of tensile force and geometry of soil disruption plans from Dechao and Yusu (1992). Therefore, the force opposing the movement of the tool into the soil should also be variable.

Only few studies in the literature have addressed this issue. According to Glancey et al. (1989), the soil breaking process is fairly complex, with two to three dominant frequencies. They are dependent on the condition of the soil, the depth and speed of operation. By increasing the travel speed reduces the distance of the breakup. These same authors worked with ripper and observed that disruption of the soil in front of the rod occurred at frequencies from 3.85 to 4.88 cycles per meter, i.e. the front ranged from 204.91 to $259.74 \mathrm{~mm}$. Reis and Sverzut (1995) worked with rigid rods ripper and registered no influence of operating speed on the soil breaking frequency.

Table 4 lists the values of the breakdown of soil bulk density, penetration rate and area of the cone base. Soil bulk density showed differences in the values of resistance independent from other factors (Figure 1c), with the models presented in table 2. Comparing the values for resistance according to the area of the cone base, within each penetration
Table 5. Soil penetration resistance (MPa) according to soil moisture, penetration rate and area of the cone base

$\begin{array}{cccc}\begin{array}{c}\text { Moisture } \\ \left(\mathbf{k g ~ k g}^{-1}\right)\end{array} & \begin{array}{c}\text { Penetration } \\ \text { rate }\left(\mathbf{m m ~ s}^{-1}\right)\end{array} & \begin{array}{c}\text { Area of the cone base }\left(\mathbf{m m}^{\mathbf{2}}\right) \\ \mathbf{1 0 . 9 8}\end{array} & \mathbf{1 2 9 . 2 8} \\ \mathbf{0 . 1 6 0} & \mathbf{0 . 1 6 6} & 4.51 \mathrm{Ab} \alpha & 1.87 \mathrm{Ba} \alpha \\ & \mathbf{3 0} & 5.47 \mathrm{Aa} \alpha & 1.97 \mathrm{Baa} \\ \mathbf{0 . 2 2 0} & \mathbf{0 . 1 6 6} & 3.38 \mathrm{Ab} \beta & 1.25 \mathrm{Ba \beta} \\ & \mathbf{3 0} & 3.69 \mathrm{Aa} \beta & 1.14 \mathrm{Ba \beta} \\ \text { DMS } & =0.175 \mathrm{DMS}=0.175 \mathrm{DMS}=0.175 \mathrm{CV}(\%)=10.54\end{array}$

Lowercase letters: compares the area of the cone base by setting the moisture and penetration rate. Greek letters: compares the rate by setting the moisture and area of the cone base. Means followed by the same letter are not significantly different by Scott-Knott test, at 0.05 probability. DMS: least significant difference. CV: coefficient of variation.

rate, it is evidenced that all had significant difference. The resistance values depending on the penetration rate were different when comparing the data obtained with the smaller cone base, regardless of the soil bulk density, the lowest rate always presented the lowest values.

The effect of penetration rate and size of the cone base on the values of the penetration resistance of a fine texture soil and of a coarse soil was also analyzed by Turnage (1974) who verified that the latter was dramatically affected by the penetration rate values.

This relationship was also examined by Hendrick and Gill (1973), which claimed that by moving the soil the tool produces stress waves and elastic and plastic deformation zones appear around the tool, and the resistance offered by the soil to the movement of a tool increases with the increase in speed, but there are indications that the increased speed of the tool decreases propagation velocity of the stress wave, decreasing the area of plastic deformation. 
The last breakdown of interactions is presented in table 5. The smaller base showed the highest resistance values independent of moisture and rate. The rates of penetration, within moisture, only influenced the values obtained with the smallest cone base. In turn, soil moisture changed the value of soil resistance to penetration, with the lowest moisture presenting the highest values. These results indicate that the smaller cone base was more efficient in capturing differences between the tests.

In a broader analysis, it is clear the wide variation in the resistance to penetration due to the methodology employed, whether or not standardized, which may lead to incorrect inferences and prevent to compare studies that use different methodologies. It is still evident, the need to standardize the methodological procedures to remedy disparities in values, common in soil science studies that focus on the resistance to penetration.

\section{CONCLUSION}

The relationship between soil penetration resistance and moisture is influenced by the value of soil bulk density.

The reduction in the area of the cone base leads to an increase in the value of the penetration resistance.

The operating speed influences the value of penetration resistance when working with the smallest base cone.

It is not possible to compare the resistance values in tests employing different base areas and penetration rates.

\section{REFERENCES}

AMERICAN SOCIETY OF AGRICULTURAL AND BIOLOGICAL ENGINEERS - ASABE. Standard S313.2: Soil cone penetrometer. St. Joseph: ASABE, 2006a. p.903-904.

AMERICAN SOCIETY OF AGRICULTURAL AND BIOLOGICAL ENGINEERS - ASABE. Standard EP542: Procedures for using and reporting data obtained with the soil cone penetrometer. St. Joseph: ASABE, 2006b. p.1053-1055.

ASSIS, R.L.; LAZARINI, G.D.; LANÇAS, K.P.; CARGNELUTTI FILHO, A. Avaliaçáo da resistência do solo à penetração em diferentes solos com a variaçáo do teor de água. Engenharia Agrícola, v.29, p.558568, 2009. http://dx.doi.org/10.1590/S0100-69162009000400006

BERGAMIN, A.C.; VITORINO, A.C.T.; FRANCHINI, J.C.; SOUZA, C.M.A.; SOUZA, F.R. Compactação em um Latossolo Vermelho Distroférrico e suas relaçóes com o crescimento radicular do milho. Revista Brasileira de Ciência do Solo, v.34, p.681-691, 2010. http://dx.doi.org/10.1590/S0100-06832010000300009

BEUTLER, A.N.; CENTURION, J.F.; SILVA, A.P. Comparação de penetrômetros na avaliação da compactação de Latossolos. Engenharia Agrícola, v.27, p.146-151, 2007. http://dx.doi.org/10.1590/S010069162007000100008
BRADFORD, J.M. Penetrability. In: KLUTE, A. (Ed.). Methods of soil analysis. 2.ed. Madison: American Society of Agronomy, Soil Science Society of America, 1986. p.463-478.

CUNHA, J.P.A.R.; VIEIRA, L.B.; MAGALHÁES, A.C. Resistência mecânica do solo à penetração sob diferentes densidades e teores de água. Engenharia na Agricultura, v.10, p.1-7, 2002.

DECHAO, Z.; YUSU, Y. A dynamic model for soil cutting by blade and tine. Journal of Terramechanics, v.29, p.317-327, 1992. http:// dx.doi.org/10.1016/0022-4898(92)90003-3

DEXTER, A.R.; CZYZ, E.A.; GATE, O.P. A method for prediction of soil penetration resistance. Soil Tillage Research, v.93, p.412-419, 2007. http://dx.doi.org/10.1016/j.still.2006.05.011

EMPRESA BRASILEIRA DE PESQUISA AGROPECUÁRIA - EMBRAPA. Centro Nacional de Pesquisa de Solos. Sistema Brasileiro de classificação de solos. 2.ed. Rio de Janeiro: Embrapa Solos, 2006. 306p.

FIGUEIREDO, G.C.; SILVA, A.P.; TORMENA, C.A.; GIAROLA, N.F.B.; MORAES, S.O.; ALMEIDA, B.G. Improvement of a testing apparatus for dynamometry: procedures for penetrometry and influence of strain rate to quantify the tensile strength of soil aggregates. Revista Brasileira de Ciência do Solo, v.35, p.373-387, 2011. http://dx.doi. org/10.1590/S0100-06832011000200008

GLANCEY, J.L.; UPADHYAYA, S.K.; CHANCELLOR, W.J.; RUMSEY, J.W. An instrumented chisel for the study of soil-tillage dynamics. Soil \& Tillage Research, v.14, p.1-24, 1989. http://dx.doi. org/10.1016/0167-1987(89)90017-2

GOMES, A.S.; PEÑA, Y.A. Caracterização da compactação através do uso do penetrômetro. Lavoura Arrozeira, v.49, p.18-20, 1996.

HENDRICK, J.G.; GILL, W.R. Soil reaction to high speed cutting. Transactions of the ASAE, v.16, p.401-403, 1973.

HERNANZ, J.L.; PEIXOTO, H.; CERISOLA, C.; SÁNCHEZGIRÓN, V. An empirical model to predict soil bulk density profiles in field conditions using penetration resistance, moisture content and soil depth. Journal of Terramechanics, v.37, p.167-184, 2000. http:// dx.doi.org/10.1016/S0022-4898(99)00020-8

LETEY, J. Relationship between soil physical properties and crop productions. Advances Soil Science, v.1, p.277-294, 1985. http:// dx.doi.org/10.1007/978-1-4612-5046-3_8

LOWERY, B.; MORRISON JUNIOR, J.E. Soil penetrometers and penetrability. In: DANE, J.H.; TOPP, G.C. (Ed.). Methods of Soil Analysis: physical methods. Madison: Soil Science Society of America, 2002. p.363-388.

MINITAB. Minitab for Windows - Version 16 PA. Pensilvânia: State College, 2012.

REICHERT, J.M.; SUZUKI, L.E.A.S.; REINERT, D.J.; HORN, R.; HAKANSSON, I. Reference bulk density and critical degreeof-compactness for no-till crop production in subtropical highly weathered soils. Soil Tillage Research, v.102, p.242-254, 2009. http:// dx.doi.org/10.1016/j.still.2008.07.002

REIS, A.; SVERZUT, C.B. Análise espectral das forças no sistema de engate de três pontos do trator agrícola. Revista Brasileira de Agrociência, v.1, p.19-22, 1995. 
SÁ, M.A.C.; SANTOS JUNIOR, J.D.G.; RESCK, D.V.S.; FERREIRA, E.A.B.; FRANZ, C.A.B. Minipenetrômetro dinâmico para determinação da resistência à penetraçáo em amostras de solo indeformadas. Pesquisa Agropecuária Brasileira, v.42, p.1659-1662, 2007. http://dx.doi. org/10.1590/S0100-204X2007001100019

SPEKTOR, M. Principles of soil-tool interaction. Journal of Terramechanics, v.18, p.51-65, 1981. http://dx.doi.org/10.1016/00224898(81)90017-3
TORMENA, C.A.; ARAÚJO, M.A.; FIDALSKI, J.; COSTA, J.M. Variação temporal do intervalo hídrico ótimo de um Latossolo Vermelho distroférrico sob sistemas de plantio direto. Revista Brasileira de Ciência do Solo, v.31, p.211-219, 2007. http://dx.doi.org/10.1590/ S0100-06832007000200003

TURNAGE, G.W. Resistance of coarse grained soils to high speed penetration.. Vicksburg: U.S. Army Waterways Experimental Station, 1974. Tech. Report No.3-652. 